\title{
Zmiany w budowie twarzowej części czaszki u pacjentów z rozszczepem podniebienia - na podstawie piśmiennictwa i doświadczeń własnych
}

\author{
Changes in orofacial morphology in cleft palate patients - on a overview literature \\ and own experience
}

\author{
'Zakład Stomatologii Zintegrowanej, Pomorski Uniwersytet Medyczny w Szczecinie \\ Department of Integrated Dentistry, Pomeranian Medical University in Szczecin, Poland \\ 2 Zakład Ortopedii Szczękowej i Ortodoncji, Instytut Matki i Dziecka w Warszawie \\ Department of Maxillary Orthopaedics and Orthodontics, Mother and Child Institute in Warsaw, Poland
}

DOI: http://dx.doi.org/10.20883/df.2021.4

\begin{abstract}
STRESZCZENIE
Rozszczep podniebienia to najczęstsza wada rozwojowa twarzowej części czaszki, która w istotny sposób wpływa na zaburzenia morfologii i funkcji układu stomatognatycznego. W zależności od objętych struktur, wada ta może mieć różny stopień nasilenia i obraz kliniczny. Do powstania wady dochodzi już w okresie wczesnej embriogenezy, podczas tworzenia się poszczególnych struktur twarzowej części czaszki, a konsekwencje jej wystąpienia, większości pacjentów, towarzyszą przez całe życie. Nie ulega wątpliwości fakt, iż osoby, u których stwierdzono rozszczep, powinny zostać objęte szczególną opieką lekarską, która uwzględniałaby ich wielospecjalistyczne potrzeby lecznicze.

Celem niniejszej pracy jest usystematyzowanie i przedstawienie aktualnej wiedzy na temat zmian w budowie twarzowej części czaszki oraz ich implikacji klinicznych u pacjentów z rozszczepem podniebienia na podstawie dostępnej literatury oraz doświadczeń własnych.
\end{abstract}

Słowa kluczowe: rozszczep podniebienia, morfologia twarzowej części czaszki, cefalometria.

\section{ABSTRACT}

Cleft palate is the most common developmental defect of the facial part of the skull, which significantly affects morphology and function of the stomatognatic system. Depending on the structures covered, this defect may have varying degrees of severity and clinical picture. The formation of the defect occurs already in the period of early embryogenesis, during the formation of individual facial structures of the facial part of the skull, and yet the consequences of its occurrence, for most patients, accompany throughout life. There is no doubt that people who have been diagnosed with orofacial cleft should be given special medical care that takes into account their multi-specialist medical needs.

The purpose of this work is to systematize and present current knowledge of changes in the facial structure of the skull and their clinical implications in cleft palate patients on the basis of available literature and own experience.

Keywords: cleft palate, orofacial morphology, cephalometry.

\section{Wstęp}

Wady rozszczepowe twarzowej części czaszki to drugie (po stulejce) najczęściej występujące wady rozwojowe u dziecka. Ich częstość występowania sięga od 1/300 do 1/2500, w zależności od różnic geograficznych, pochodzenia etnicznego, a także statusu socjoekonomicznego badanej populacji. W Polsce rozszczepy wargi z lub bez rozszczepu podniebienia obecne są u 1 na 1000 żywo urodzonych dzieci [1].

Rozszczepy twarzowej części czaszki przedstawiają istotny problem zdrowotny w społeczeństwie, ponieważ ich leczenie wymaga wdrożenia złożonego i wielodyscyplinarnego chirurgicznego, ortodontycznego, stomatologicznego, foniatrycznego, a także psychologicznego postępowania leczniczego. Wady te znajdują implikacje w budowie kostnej twarzowej części czaszki, jak i charakterystyce tkanek miękkich na poziomie makroskopowym i histologicznym [2].

Wady rozszczepowe mogą charakteryzować się różnym zakresem dotkniętych struktur. Oczywiście wiąże się to $z$ czasem powstania wady $w$ życiu płodowym, z czynnikami działającymi na zarodek w czasie embriogenezy, a także predyspozycjami genetycznymi. Dla większości wad zespołowych czynniki przyczyniające się do powstawania rozsz- 
czepów zostały poznane. Natomiast badania nad genetycznym podłożem dwóch fenotypów izolowanych zaburzeń, tj. rozszczepu wargi występującego $z$ lub bez rozszczepu podniebienia (ang. cleft lip/palate, CL/P) i rozszczepu podniebienia (cleft palate) nadal trwają. Te złożone, wrodzone wady rozwojowe mają odmienną etiologię wynikającą z zaburzeń genetycznych, ekspozycji na czynniki środowiskowe i/lub interakcji powyższych. Mimo iż ich podłoże powstawania w dużej mierze pozostaje nieznane, przyjęto, że w większości to właśnie współwystępowanie czynników środowiskowych i genetycznych stanowi przyczynę tych zaburzeń, przy czym rozszczep podniebienia w większym stopniu jest wynikiem zaburzeń dziedzicznych i ze względu na swą odmienną etiologię, potwierdzoną przez badania epidemiologiczne, często jest uważany za osobną jednostkę kliniczną [3-5].

Celem niniejszej pracy jest usystematyzowanie i przedstawienie aktualnej wiedzy na temat zmian w budowie twarzowej części czaszki oraz ich implikacji klinicznych u pacjentów z rozszczepem podniebienia na podstawie dostępnej literatury oraz doświadczeń własnych.

\section{Etiopatogeneza}

Rozwój twarzy rozpoczyna się w 5. tygodniu życia płodowego od utworzenia się pięciu wyniosłości: dwóch wyrostków żuchwowych, dwóch wyrostków szczękowych oraz jednego wyrostka czołowego, który następnie dzieli się na wyrostki nosowe, przyśrodkowe i boczne; sąsiadujące wyrostki zrastają się z sobą i z nich powstaje chrzęstna i kostna część szkieletu twarzy [6, 7].

Do powstania wady dochodzi w okresie wczesnej embriogenezy, podczas tworzenia się poszczególnych struktur. Rozwój podniebienia jest złożonym procesem wymagającym wystąpienia ściśle określonej sekwencji zdarzeń. Podczas szóstego tygodnia życia płodowego z górnej części pierwszego łuku skrzelowego wykształcają się wyrostki szczękowe, a na wyrostku czołowym pojawiają się parzyste wyrostki nosowe, przyśrodkowe i boczne. Do siódmego tygodnia rozwoju płodu przyśrodkowe i boczne wyrostki nosowe łączą się z wyrostkiem szczękowym, tworząc podniebienie pierwotne i środkową część górnej wargi oraz nos. Pomiędzy 8. a 12. tygodniem wyrostki podniebienne (wychodzące z wyrostków szczękowych) oraz blaszki poziome kości podniebiennych, tzw. płyty podniebienne - zlewają się, formując podniebienie twarde i miękkie wraz z języczkiem [8]. Ku przodowi, płyty podniebienne łączą się z leżącym do przodu, już ukształtowanym, środkowym segmen- tem szczęki (powstałym w wyniku łączenia się wyrostków nosowych), a przetrwałą pozostałością po tym procesie jest występowanie otworu przysiecznego (łac. foramen incisivum). Procesy te wymagają interakcji tkanki mezenchymalnej i nabłonka, migracji, różnicowania i programowanej śmierci komórek, w obecności rozpuszczalnych czynników wzrostu i substancji międzykomórkowej [6, 7]. Nieprawidłowość $w$ choćby jednym z miejsc łączenia się struktur budujących podniebienie skutkuje powstaniem rozszczepu, czasami wraz z towarzyszącymi nieprawidłowościami zębowymi [8-10].

Teoretycznie rozszczep wargi górnej powinien się pojawiać w linii pośrodkowej ciała na skutek braku połączenia wyrostków nosowych przyśrodkowych, ale na ogół jest on usytuowany od niej bocznie, czasami obustronnie. Ponieważ opisane wyżej wyrostki nosowe uczestniczą $w$ formowaniu nie tylko części podniebienia, ale i wyrostka zębodołowego wraz z górnymi zębami siecznymi, można również zaobserwować rozszczep wyrostka nawet wówczas, gdy nie obejmuje on podniebienia wtórnego. Zamykanie podniebienia wtórnego następuje dwa tygodnie po uformowaniu się podniebienia pierwotnego, co wiąże się z tym, że wszelkie zaburzenia budowy tkanek podniebienia pierwotnego, w tym wargi mogą wpływać na budowę tkanek powstających później [9].

Warto zauważyć, iż u $60 \%$ osób z rozszczepem wargi (CL/P) występuje także rozszczep podniebienia (CP). Izolowany rozszczep podniebienia wtórnego jest spowodowany czynnikiem, który zadziałał już po zakończeniu tworzenia się warg. Natomiast niecałkowity rozszczep podniebienia wtórnego wskazuje na działanie szkodliwych czynników w końcowych etapach tego procesu [9].

\section{Anatomia rozszczepów}

Podstawowym zaburzeniem morfologii w rozszczepach twarzowej części czaszki jest brak ciągłości tkanek w obrębie wargi, wyrostka zębodołowego, podniebienia twardego i miękkiego lub jednej z tych struktur. W niektórych rodzajach rozszczepów zaburzenia budowy anatomicznej są niewielkie. Dzieje się tak, na przykład, w podskórnym rozszczepie wargi, rozszczepie czerwieni wargi oraz rozszczepie języczka podniebienia miękkiego. W innych mogą być znacznie bardziej nasilone. Najpoważniejsze zaburzenia morfologii oraz funkcji obserwuje się w rozszczepach całkowitych jedno- i obustronnych podniebienia pierwotnego i wtórnego [3, 10]. Najczęściej występujące podtypy rozszczepów przedstawione zostały na rycinie 1. 

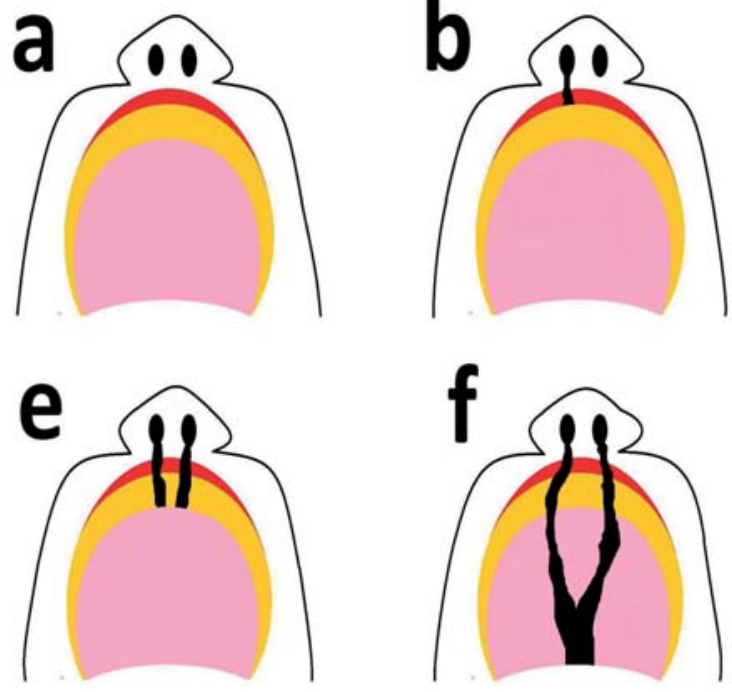
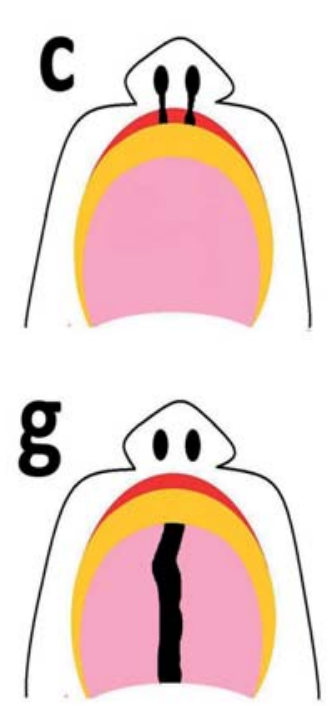
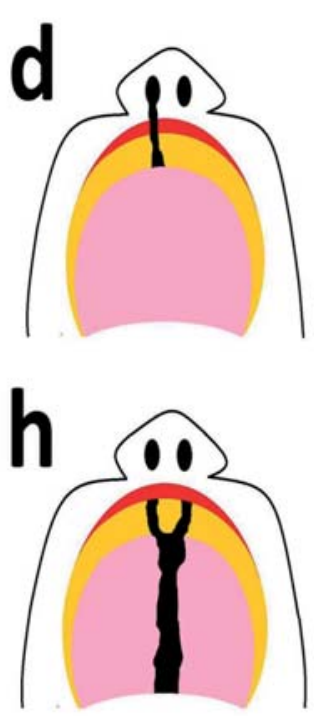

Rycina 1. Najczęściej występujące podtypy wad rozszczepowych twarzowej części czaszki. Podniebienie bez rozszczepu (a), rozszczep wargi: jednostronny (b) i obustronny (c), rozszczep wargi i podniebienia twardego: jednostronny (d) i obustronny (e), całkowity rozszczep wargi i podniebienia (f), rozszczep podniebienia: rozszczep podniebienia miękkiego (g) i rozszczep podniebienia miękkiego i twardego (h). Na czerwono zaznaczono wargę, żółto - podniebienie twarde, różowo - podniebienie miękkie. Ciemne linie reprezentują szczelinę rozszczepu [według rysunku autora].

Figure 1. The most common subtypes of orofacial clefts. Unaffected healthy palate (a), cleft lip only: unilateral (b) and bilateral (c), cleft lip and hard palate: unilateral (d) and bilateral (e), complete lip and palate cleft (f), cleft palate only: soft palate cleft (g) and soft and hard palate cleft (h). The red colour represents lip, yellow - hard palate, pink - soft palate. The dark bars represent the cleft [according to drawing of the author].

Prawidłowy rozwój dolnej części szczęki zależy od następujących czynników: strzałkowego i pionowego ruchu kości podniebiennych i szczęk en bloc oraz aktywności szwów oddzielających je od lemiesza i podstawy czaszki, a także poprzecznego i pionowego rozwoju sklepienia podniebienia [11].

Po zamknięciu rozszczepu podniebienia, za pomocą klasycznych technik chirurgicznych, w których błona śluzowa pokrywająca lemiesz jest wykorzystywana do odtworzenia błony śluzowej podniebienia wtórnego od strony jamy nosowej, lemiesz i płyty podniebienne są połączone włóknistą blizną, która teoretycznie uniemożliwia normalną aktywność. Blizna ta hamuje rozwój i powoduje obniżenie podniebienia. Zamknięcia szczeliny rozszczepu podniebienia twardego dokonuje się poprzez szerokie odwarstwienie płata śluzówkowo-okostnowego i użycia tylko błony śluzowej podniebienia pokrywającej marginesy rozszczepu. W niektórych przypadkach można to osiągnąć poprzez przyśrodkowe przemieszczenie niewielkich płatów śluzówkowo-okostnowych sklepienia podniebienia [11].

\section{Charakterystyczne cechy budowy twarzowej części czaszki u pacjentów z rozszczepem podniebienia}

\section{A. Najczęściej stosowane metody służące do oceny morfologii twarzowej części czaszki}

Zmiany morfologiczne twarzowej części czaszki najczęściej są oceniane na bocznych zdjęciach cefalometrycznych i tomografii stożkowej. Badania te znajdują szerokie zastosowanie $w$ diagnostyce pacjentów, u których występują wady wrodzone i obecnie wykonanie ich jest złotym standardem w ortodoncji (ryciny 2 i 3). W praktyce klinicznej u pacjentów rozszczepowych Instytutu Matki i Dziecka wykonuje się rutynowo zdjęcia cefalometryczne w wieku 5, 10 i 15 lat oraz dodatkowo $w$ innych punktach czasowych według bieżących wskazań, podobnie jak tomografię stożkową, która pozwala ocenić np. grubość kości przed i po przeszczepie kości do wyrostka zębodołowego. Na rycinie $\mathbf{3}$ warto zwrócić uwagę na brak ciągłości tkanek twardych w obrębie wyrostka zębodołowego i wynikającą z tego faktu potrzebę zabiegu chirurgicznego. 


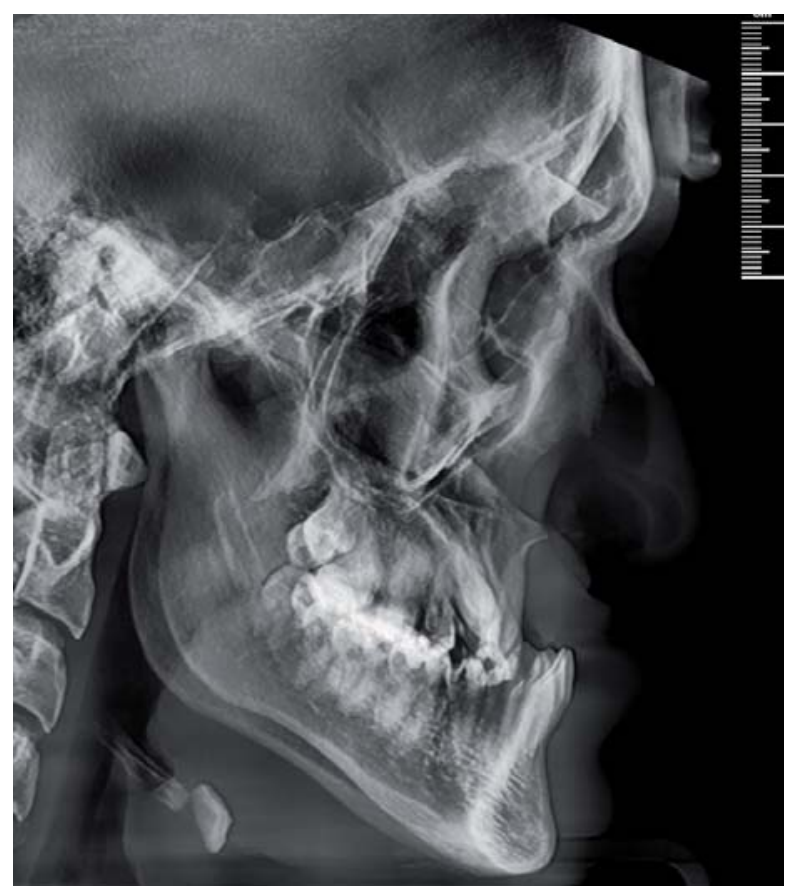

Rycina 2. Zdjęcie cefalometryczne pacjenta z rozszczepem podniebienia [zbiory własne autora]

Figure 2. Cephalometric photo of a patient with cleft palate [author's own collections]
Znanym jest fakt, że twarzowa część czaszki pacjentów $z$ rozszczepem różni się $w$ porównaniu z twarzową częścią czaszki osób bez tej wady, a sam typ twarzy jest zdeterminowany przez wpływ czynników dziedzicznych. Liczne badania pokazują, że nie tylko osoby z rozszczepem podniebienia, ale także morfologia czaszkowo-twarzowa ich biologicznych rodziców może różnić się od populacji ogólnej [12].

Wielu autorów odnotowało znaczące różnice w pomiarach wykonanych dzięki badaniom obrazowym pomiędzy grupą pacjentów po rozszczepie podniebienia i w grupie bez takiej wady.

\section{B. Morfologia szczęki i żuchwy}

Oczywiście niezmiernie ważnym czynnikiem mogącym wpływać na wyniki wspomnianych badań jest wiek pacjentów, ponieważ niektóre parametry ulegają zmianie wraz z fizjologicznym wzrostem. Przy podziale na 3 grupy wiekowe (5, 10 i 17 lat), we wszystkich 3 grupach zaobserwowano zmniejszający się wraz z wiekiem prognatyzm szczęki (kąt SNA tj. sella-nasion-punkt A wg Downsa w badaniu

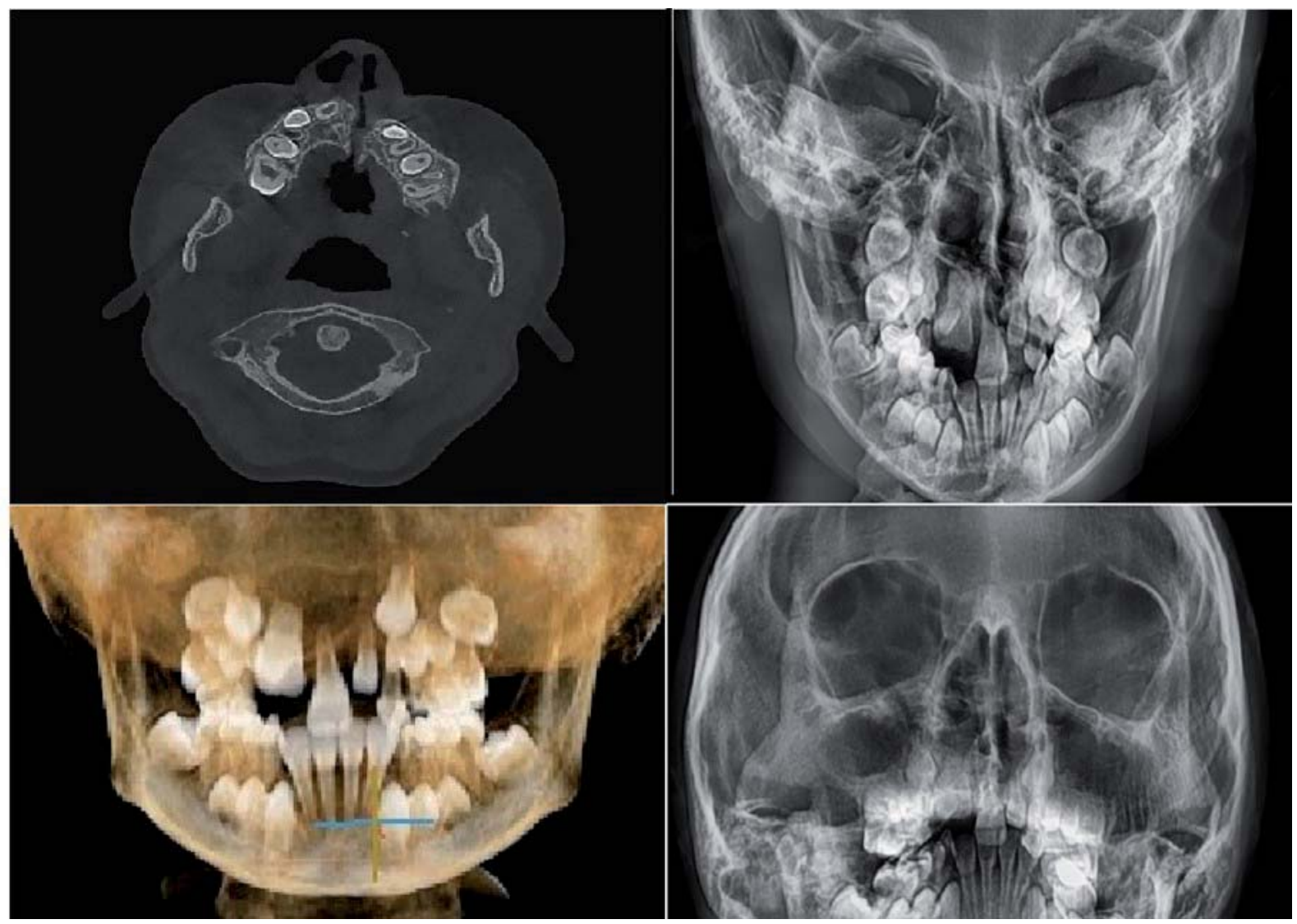

Rycina 3. Obraz pacjenta z rozszczepem podniebienia w tomografii stożkowej [zbiory własne autora]

Figure 3. Image of a patient with cleft palate in cone beam tomography [author's own collections] 
cefalometrycznym). Oznacza to, że niedorozwój szczęki w stosunku do przedniego dołu czaszki nasila się z biegiem czasu. Przednio-tylne położenie żuchwy nie wykazywało odchyleń od normy, zaś kąt żuchwy malał wraz z wiekiem, co obserwujemy także u osób zdrowych [13]. Podobne wyniki uzyskano przy podziale badanych dzieci na trzy grupy wiekowe: 4-8 lat, 9-12 lat, 13-14 lat. Wykazano stopniowe zwiększanie się pomiarów kątowych i procentowych wraz ze wzrostem pacjentów, jak również zmniejszający się kąt SNA wraz z wiekiem [14].

W badaniach mających na celu ocenę różnic w morfologii twarzowej części czaszki pacjentów operowanych i nieoperowanych z powodu rozszczepu podniebienia w różnym wieku, u których nie przeprowadzono korekty chirurgicznej, obserwowano znaczny deficyt wzrostu szczęki i żuchwy, a także dotylne położenie szczęki. Przy podziale na trzy grupy wiekowe: 4-6 lat, 10-12 lat, 16-20 lat, najwyraźniej nasilone zmiany dotyczyły pacjentów w skrajnych grupach. U osób, które były operowane we wczesnym dzieciństwie, stwierdzono zaś wyraźny wzrost wysokości dolnego piętra twarzy. Co wydaje się być istotne, w pomiarach wykonanych na telerentgenogramach nie wykazano różnic między grupą pacjentów operowanych i nieoperowanych. Można zatem wnioskować, iż zabieg chirurgiczny nie jest jedynym prowodyrem niedorozwoju szczęki, który dotyczy każdej osoby dotkniętej rozszczepem podniebienia [15].

U pacjentów z rozszczepem podniebienia szczęka znajduje się w położeniu dotylnym, w porównaniu do dzieci bez rozszczepu. Analiza danych odnośnie budowy wymienionej kości wykazała, iż wynik pomiaru długości w płaszczyźnie strzałkowej mierzony według McNamary jest mniejszy w grupie pacjentów z rozszczepem, w porównaniu do grupy osób bez wady [16-18].

Liczne badania potwierdzają, że cofnięcie i skrócenie szczęki występuje u wszystkich pacjentów z rozszczepem w obrębie podniebienia twardego i miękkiego, zarówno u tych przed i po operacji zamknięcia rozszczepu. Co ciekawe, wielu badaczy stwierdziło także obecność niedorozwoju żuchwy jako wtórnej wady do zmniejszenia wymiarów szczęki $[19,20]$. Powyższe obserwacje mogą wynikać z tego, iż wzrost żuchwy jest zależny od indywidualnego potencjału wzrostowego, równowagi czynnościowej struktur twarzowej części czaszki oraz od zrównoważonego rozkładu sił podczas kontaktu zębów w obu łukach zębowych. Zatem nie wzbudza wątpliwości fakt, iż $w$ rozszczepach podniebienia zaburzenia budowy szczęki, poprzez wzajemne oddziaływanie między elementami układu stomatognatycznego, mogą wpływać na budowę i położenie żuchwy [21, 22].

Wśród publikowanych prac można znaleźć także badania, według których nie stwierdza się istotnych zaburzeń przednio-tylnych w położeniu szczęki i żuchwy u pacjentów z rozszczepem [14], jednakże stanowią one niewielki odsetek. Znakomita większość autorów podaje, iż u pacjentów rozszczepowych zaobserwowała także skrócenie trzonu żuchwy [13, 20,22], choć i tu spotykane są nieliczne przeciwne opinie [23]. Parametrem, który jest wyraźnie większy u pacjentów z wadami wrodzonymi w porównaniu do grupy pacjentów zdrowych, jest kąt żuchwy [19], a sama kość ulega posteriorotacji [23], przy czym zwiększeniu ulega także kąt pomiędzy żuchwą a podstawą czaszki (kąt NS/ML tj. nasion-sella/mandibular line $\mathrm{w}$ badaniu cefalometrycznym) średnio o 6,30 w porównaniu do grupy kontrolnej [21]. Typowy obraz badania cefalometrycznego pacjenta z rozszczepem podniebienia przedstawia rycina 2, na której obserwujemy znaczny niedorozwój szczęki, jej skrócenie i zmniejszenie pojemności dróg oddechowych.

\section{Ustawienie zębów siecznych}

W wielu pracach podkreśla się występowanie retruzji zębów siecznych górnych i dolnych oraz, co za tym idzie, zwiększenie kąta międzysiecznego (od 5 do 130) i zmniejszenie kąta nachylenia zębów siecznych górnych do płaszczyzny przedniego dołu czaszki u pacjentów z rozszczepem podniebienia. Zmieniona morfologia szczęki oraz blizna kostna na podniebieniu mają wpływ na nachylenie zębów przednich w obu łukach zębowych. Retruzja siekaczy dolnych u pacjentów z rozszczepem podniebienia może być związana z mechanizmem kompensacji zębowo-wyrostkowej, jaki towarzyszy posteriorotacji żuchwy [21, 23].

\section{Nieprawidłowości zębowe dotyczące liczby zębów}

Hipodoncja jest zaburzeniem dotyczącym zmniejszenia liczby zębów, które najczęściej współwystępuje z rozszczepami twarzowej części czaszki. Dotychczas zidentyfikowano wiele genów, których polimorfizmy wpływają na częstość występowania obu wymienionych wad [23-26]. Co interesujące, stwierdzono istotną statystycznie różnicę w rozmieszczeniu braków zawiązków zębów w grupie pacjentów z CP i CL/P, co wskazuje na odmienną etiologię powstawania hipodoncji w poszczególnych rodzajach rozszczepów. Odsetek pacjentów z hipodoncją według badaczy waha się od 25 do $34 \%$, przy czym w populacji dzieci pol- 
skich wynosi on $29,6 \%$. Najczęściej brakującymi zawiązkami zębów stałych w grupie pacjentów z rozszczepem podniebienia były drugie zęby przedtrzonowe dolne, drugie zęby przedtrzonowe górne i siekacze boczne górne [24, 26, 27].

Ponadto u pacjentów z rozszczepem podniebienia, w różnym nasileniu, obserwuje się: zmiany przerostowe małżowin nosowych, przerost tkanki adenoidalnej tylnej ściany gardła oraz przerost migdałków podniebiennych. Jest to wyraz anatomicznej i czynnościowej kompensacji istniejącego zaburzenia morfologicznego [13].

\section{Wpływ rozszczepu podniebienia na zaburzenia funkcji układu stomatognatycznego}

Niepodważalnym jest fakt, iż wady rozwojowe prowadzą do znacznego upośledzenia takich czynności, jak: ssanie, żucie, połykanie, oddychanie, do zaburzeń mowy i słuchu [28], a także w znacznym stopniu powodują defekt estetyczny twarzy [29]. Nawet po chirurgicznym zamknięciu szczeliny rozszczepu powstaje blizna kostna, która hamuje rozwój i powoduje obniżenie podniebienia. Skutkuje to niedrożnością dróg oddechowych górnych i zwiększa tendencję do deformacji klasy III [11].

Występujące w rozszczepach nieprawidłowości budowy anatomicznej i zaburzenia czynnościowe spowodowały, że opracowano w Polsce i na świecie programy, które rozwiązują problemy związane $z$ organizacją opieki zdrowotnej nad tą grupą pacjentów i umożliwiają objęcie ich szczególną opieką. Powszechnie uznawanym modelem terapii w tej wadzie jest etapowe, zespołowe leczenie wielospecjalistyczne [28]. Oznacza to, że pacjenci dotknięci wadą wrodzoną części twarzowej czaszki nierzadko obok interwencji chirurgicznej i stomatologicznej wymagają również podjęcia terapii logopedycznej, foniatrycznej czy pomocy psychospołecznej [29-31].

\section{Wnioski}

Reasumując, można powiedzieć, że pacjentów z wadami rozszczepowymi należy objąć szczególną opieką medyczną. Skutki wady rozwojowej mają implikacje w budowie twarzowej części czaszki nawet u dorosłych pacjentów, zoperowanych w dzieciństwie. Największą zgodność autorzy wykazują co do występowania skrócenia i cofnięcia szczęki, posteriorotacji żuchwy, przechylenia zębów siecznych oraz hipodoncji.

\section{Oświadczenia}

Oświadczenie dotyczące konfliktu interesów

Autorzy deklarują brak konfliktu interesów

w autorstwie oraz publikacji pracy.

\section{Źródła finansowania}

Autorzy deklarują brak źródeł finansowania.

\section{Piśmiennictwo}

[1] Yoon YJ, Perkiomaki MR, Tallents RH, Barillas I, Herrera-Guido R, Fong CT. Transverse craniofacial features and their genetic predisposition in families with nonsyndromatic unilateral cleft lip and palate. Cleft Palate J. 2004;41:256-61. English.

[2] Shkoukani MA, Lawrence LA, Liebertz DJ, Svider PF. Cleft palate: a clinical review. Birth Defects Res C Embryo Today. 2014;102(4):333-42. English.

[3] Zawiślak A, Woźniak K, Jakubowska A, Lubiński J, Kawala B, Znamirowska-Bajowska A. Polymorphic variants in VAX1 gene (RS7078160) and BMP4 gene (RS762642) and the risk of non-syndromic ortofacial clefts in the polish population. Med. Wieku Rozw. 2014;18,1:16-22. English/Polish.

[4] Fraser FC. The genetic of cleft lip and palate. Am J Hum Genet. 1970;22:336-52.

[5] Mossey PA, Arngrimsson R, McColl J, Vintiner GM, Connor JM. Prediction of liability to orofacial clefting using genetic and craniofacial data from parents. J Med Genet. 1998;35:371-8.

[6] Sharpe PM, Ferguson MWJ. Mesenchymal influences on epithelial differentiation in developing systems. J Cell Sci. 1988;10:195-230.

[7] Cuervo R. Programmed cell death is required for palate shelf fusion and is regulated by retinoic acid. Dev Biol. 2002;245:145-156.

[8] Meikle C. Craniofacial development, growth and evaluation. Bateson Publishing, Norfolk 2002.

[9] Tessier P. Anatomical classification of facial, craniofacial and laterofacial cleft. J Maxillofac Surg. 1976; 4,69-92.

[10] Gorlin R, Cohen M, Hennekam R. Syndromes of the head and neck. Oxford University Press, 2001.

[11] Precious DS. Cleft lip and palate. In: Fonseca R, editor. Fonseca's oral and maxillofacial surgery. Philadelphia: W.B. Saunders Company. 2000;6,3,27-59.

[12] Maulina I, Urtane I, Jakobsone G. The Craniofacial Morphology of the Parents of Children with Cleft Lip and/or Palate: A Review of Cephalometric Studies. Stomatologija, Baltic Dental and Maxillofacial Journal. 2006;8:16-20.

[13] Fujita S, Suzuki A, Nakamura N, Sasaguri M, Kubota Y, Ohishi M. Retrospective evaluation of craniofacial growth of Japanese chil dren with isolated cleft palate: From palatoplasty to adolescence. Cleft Palate Craniofac J. 2005;42:625-33.

[14] Friede H, Persson EC, Lilja J, Elander A, LohmanderAgerskov A, Soderpalm E. Maxillary dental arch and occlusion in patients with repaired clefts of the secondary palate. Scand J Plast Reconstr Hand Surg. 1993;27:297-305. 
[15] Jain P, Agarwal A, Srivastava A. Ocena cefalogramów bocznych u pacjentów z rozszczepami podniebienia. Pol Prz Chir. 2009;81:37-43.

[16] Shibasaki Y, Ross RB. Facial growth in children with isolated cleft palate. Cleft Palate J. 1969;6:290-302.

[17] Berkovitz BKB, Holland GR, Moxham BJ. Oral anatomy, histology and embryology. Mosby/Elselvier 2009.

[18] Hermann NV, Kreiborg S, Darvann TA, Jensen BL, Dahl E, Bolund S. Craniofacial morphology and growth comparisons in children with Robin Sequence, isolated cleft palate, and unilateral complete cleft lip and palate. Cleft Palate Craniofac J. 2003;40: 373-96.

[19] Smahel Z. Cefalometric and morphologic changes in adult males with isolated cleft palate. Acta Chir Plast. 1983;25:113-26.

[20] Smahel Z, Brousilova M, Mullerova Z. Craniofacial morphology in isolated cleft palate prior to palatoplasty. Cleft Palate J. 1987;24:200-8.

[21] Bishara SE. Cephalometric evaluation of facial growth in operated and non-operated individuals with isolated clefts of the palate. Cleft Palate J. 1973; 3:239-46.

[22] Eriksen J, Hermann NV, Darvann TA, Kreiborg S. Early postnatal development of the mandible in children with isolated cleft palate and children with nonsyndromic Robin Sequence. Cleft Palate Craniofac J. 2006;43:160-7.

[23] Becker M, Svensson H, McWilliam J, Sarnas KV, Jacobsson S. Adult skeletal profile in isolated cleft palate: a comparison of the von Langenbeck and Wardill procedures for primary repair of the palate. Scand J Plast Reconstr Hand Surg. 2001;35:387-97.

[24] Andersson EM, Sandvik L, Abyholm F, Semb G. Cle$\mathrm{fts}$ of the secondary palate referred to the Oslo Cleft Team: epidemiology and cleft severity in 994 individuals. Cleft Palate Craniofac J. 2010;47:335-42.
[25] Smahel Z, Horak I, Polivkova H, Skvarilova B. Configuration of facial profile in adults with isolated cleft palate. Acta Chir Plast. 1992;34:204-14.

[26] Matern O, Sauleau EA, Tschill P, Perrin-Schmitt F, Grollemund B. Left-sided predominance of hypodontia irrespective of cleft sidedness in a French population. Cleft Palate Craniofac J. 2012;49:e1-5.

[27] Shapira Y, Lubit E, Kuftinec MM. Hypodontia in children with various types of clefts. Angle Orthod. 2000;70:16-21.

[28] Małkiewicz E. Wielospecjalistyczne zespołowe leczenie dzieci z rozszczepem podniebienia pierwotnego i/ lub wtórnego. Ortop Szczęk Ortod. 2002;4, $1,5-9$.

[29] Neilson DE. Mixed clefting type in Rapp-Hodgkin syndrome. Am J Med Genet. 2002;108:281-284.

[30] Lidral AC, Murray JC. Genetic approaches to identify disease genes for birth defects with cleft lip/palate as a model. Birth Defects Res. A Clin. Mol. Teratol. 2004;70,12:893-901.

[31] Schutte BC, Murray JC. The many faces and factors of orofacial clefts. Hum. Mol. Genet. 1999;8,10:1853-1859.

Zaakceptowano do edycji: 28.06.21

Zaakceptowano do publikacji: 29.09.21

\section{Adres do korespondencji:}

Alicja Zawiślak

Zakład Stomatologii Zintegrowanej

Pomorski Uniwersytet Medyczny w Szczecinie

Al. Powstańców Wlkp. 72

70-111 Szczecin

tel. (91) 4661692

e-mail: alicja.zawislak@pum.edu.pl 